\title{
The plant-louse Leuronota calycophylli sp. n. (Homoptera, Psylloidea), a pest on the timber species Calycophyllum spruceanum (Rubiaceae) in Peru
}

\author{
Daniel Burckhardt \\ Muséum d'Histoire Naturelle, Geneva, Switzerland \\ Guy Couturier \\ Muséum National d'Histoire Naturelle, Entomologie, Antenne ORSTOM, \\ Paris, France
}

\begin{abstract}
Leuronota calycophylli sp. $\mathrm{n}$. attacks experimental plantations of the high-quality timber Calycophyllum spruceanum in Peru. Adults, larvae and the damage on the host are described and illustrated. Adults differ from other congeners in the absence of genal processes and in the structure of the genitalia. The host of L. calycophylli is unusual for psylloids: rubiacious hosts are otherwise known only from the four members of the Palaearctic Trioza galii Förster group and the Taiwanese Synpsylla wendlandiae Yang.
\end{abstract}

\section{Introduction}

Several species of the small rubiaceous genus Calycophyllum, which occurs in tropical America, are exploited for high-quality timber (Record \& Hess, 1943; Uphof, 1968; Mabberley, 1987). The Instituto de Investigaciones de la Amazonia peruana (IIAP) has experimental plantations of Calycophyllum spruceanum, locally known as capirona, which are situated on the bank of the Ucayalli river near lquitos. In the region capirona is much used for poles, boards, timber, firewood, etc. Young plants are attacked by a species of the homopterous jumping plant-lice (Psylloidea), causing considerable damage. It is a hitherto unknown species of Leuronota (Triozidae) which is described below.

Psylloid species exhibit a high degree of specificity towards their mostly dicotyledonous hosts. Restricted host ranges are found also at higher systematic level where related psylloid taxa tend to develop on related plant taxa. This is well-exemplified by the small families Homotomidae (on Ficus spp.), Carsidaridae (on Malvales), Phacopteronidae (on Rutales) and the ill-defined Calophyidae (on Rutales). In the large family Psyllidae, again, many subfamilies, tribes or

Correspondence: Dr Daniel Burckhardt, Muséum d'histoire naturelle, Case postale 6434, CH-1211 Genève 6, Switzerland. generea exhibit narrow host ranges (White \& Hodkinson, 1985; Hollis, 1987a, 1987b; Burckhardt \& Lauterer, 1989; Hollis \& Broomfield, 1989; Burckhardt, 1991). In the speciose Triozidae, these patterns seem less strict, though they may be obscured by the current artificial classification (Hollis, 1984).

Some plant families are particularly well-represented among psylloid hosts such as the Fabaceae, Myrtaceae and Asteraceae. The Rubiaceae are, with about 650 genera and 10,700 species, the fourth largest family of angiosperms (Robbrecht, 1988) but host surprisingly few psylloids. Several published records are dubious: Cinchona was erroneously recorded as host of Euceropsylla cayeyensis (Caldwell) and E. russoi Boselli, which both develop on the fabaceous Inga (Hodkinson \& White, 1981); the record of Anthocephalus indicus as host of Pauropsylla reticulata Mathur may concern a misidentified Ficus sp. (Moraceae) (Hollis, 1984, pers. comm.); and Conciata laevipes listed by Gegechkori \& Loginova (1990) is an unlikely host of Trioza schrankil Flor, which develops on Astrantia spp. (Apiaceae). Rubiaceous hosts are likely or confirmed only for the following taxa: the Taiwanese Synpsylla wendlandiae Yang (Psyllidae) on Wendlandia formosana (Cinchonoideae, Rondeletieae) and the palaearctic Trioza galii Förster group on several genera of Rubioidea, Rubieae. The Trioza galit Förster 
group was placed by Conci (1992), who defined and revised the group, in Spanioza Enderlein with the following species: S. galii (Förster) on Galium spp., Asperula spp., Sherardia arvensis and Rubia peregrina (all Rubiaceae); S. rubıae (Baeva) on Rubia rubiflorae; S. rubicunda (Loginova) on Galium sp.; and S. tamanini Conci possibly on Galtum antsophyllum. In the absence of phylogenetically convincing arguments this narrow generic concept is not followed here and the group is referred to the large, artificial genus Trioza. Another record concerns Chomelia asiatica (Cinchonoideae, Cinchoneae) from India which was assigned to an unidentified psylloid (Mani, 1973; Hodkinson, 1986).

\section{Leuronota calycophylli sp. n.}

(figs 1-8)

Description. Adult. Coloration Head and thorax ochreous dorsally with slightly darker longitudinal stripes, and straw-coloured laterally and ventrally. Compound eyes dark reddish-brown. Antennae yellow, segments 3-8 black-tipped, 9 and 10 entirely black. Abdomen dark brown above, pale-yellow beneath. Legs yellow. Fore wings transparent with yellow veins, sometımes with yellowish tint at radular areas; hind wings transparent. Younger specimens lighter with less expanded dark coloration.

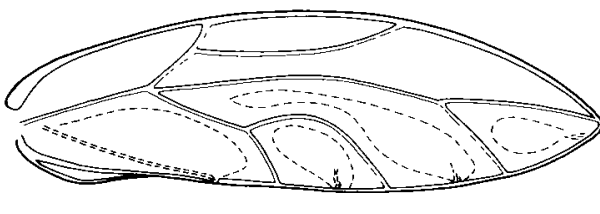

1

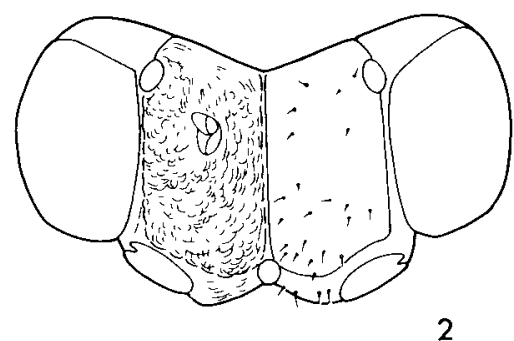

2

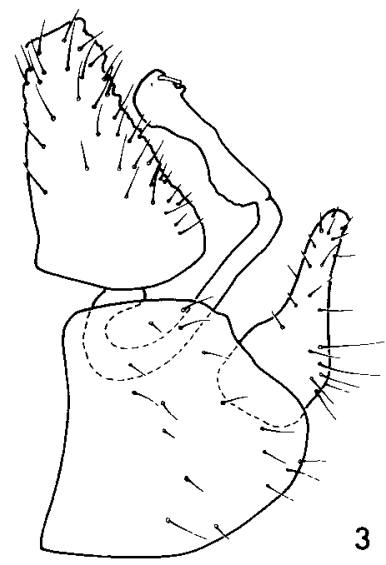

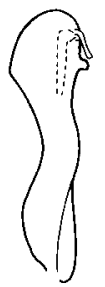

5

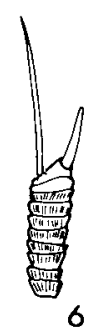

4

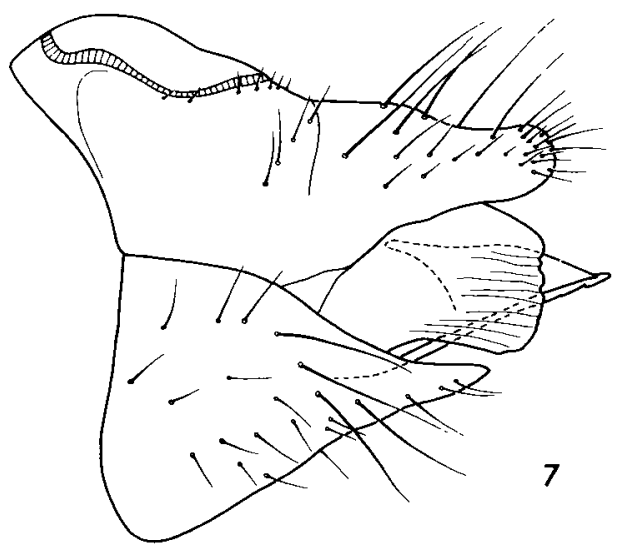

Figs. I-7. Leuronota calycophylli sp. n.: I, fore wing; 2, head, dorsal view; 3, male termınalia, lateral view; 4, paramere, inner surface; 5 , distal segment of aedeagus; 6 , antennal segment 10,7 , female terminalia, lateral view. 


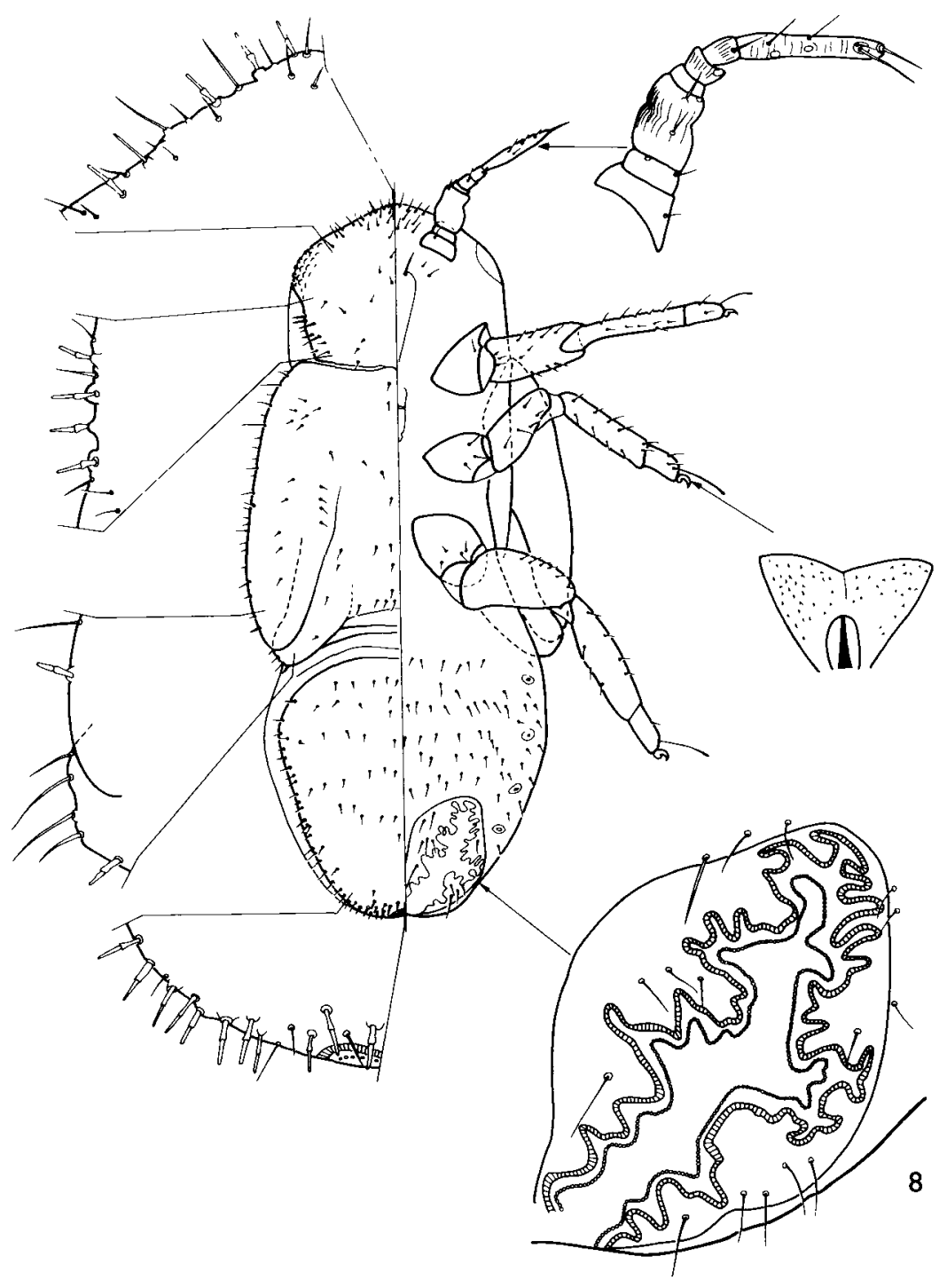

Fig. 8. Leuronota calycophyll sp. n., fifth instar larva; left dorsal view, right ventral view.

Structure. Head (fig. 2) with sculptured vertex, slightly weaker medially than laterally; genal processes absent, genae forming at most small tubercles. Antennal segment 10 and longer terminal seta subequal in length, about twice as long as shorter seta which is truncate apically (fig. 6). Fore wings (fig. 1) narrowly lanceolate, acute apically; vein Rs short, concave; bifurcation of vein $M$ distinctly distal to line joining the apices of veins $\mathrm{Rs}$ and $\mathrm{Cu}_{\mathrm{ra}}$; cell $\mathrm{M}_{1-2}$ and $\mathrm{Cu}_{\mathrm{ta}}$ subequal. Surface spinules in males present in cells $\mathrm{m}_{1-2}, \mathrm{~m}_{3-4}, \mathrm{cu}_{\mathrm{ia}}$ and $\mathrm{cu}_{\mathrm{ib}}$, denser basally than apically; in females surface spinules present also in other cells, fields larger, in cell $c+s c$ in the center, in $r_{1}$ a few irregularly spaced spinules, in rs mainly subapically. In both sexes more or less evenly spaced apically, slightly denser and more irregular basally. Radular spinules forming narrowly triangular stripes in cells $\mathrm{m}_{\mathrm{I}+2}, \mathrm{~m}_{3+4}$ and $\mathrm{cu}_{\mathrm{ta}}$. Lateral setae present on abdominal tergite 3 in males and 4 in females. Terminalia as in figures $3-5,7$. Male proctiger relatively short, subgenital plate subglobular. Parameres bearing a subquadrangular base with a group of long setae at the hind margin and a slender process sparsely covered in medium long setae; apex strongly sclerotized. Basal portion of aedeagus narrowly bent basally, slender and straight apically; apical portion constricted in the middle, apex irregularly rounded, with rectangular tubercle dorsally; sclerotized end tube of ductus ejaculatonus slender, weakly sinuate. Female terminalia short, dorsal margin of proctiger weakly sinuous, apex blunt; proctiger bearing long setae dorsally forming indistinct longitudinal rows; with weak transverse sclerotization distal to circum-anal ring. Subgenital plate shorter than proctiger, pointed apically. Ventral margin weakly concave in apical half. Valvulae 1 with 2 ventral subapical teeth, valvulae 2 irregularly triangular, valvulae 3 flattened apically.

Measurements in mm and ratios $(20,29)$. Head width (HW) 0.43 -0.52; antenna length (AL) 1.08-1.19; fore wing length (WL) 2.26-2.85; male proctiger length (MP) $0.15-0.16$; paramere length $0.15-0.16$; length of distal segment of aedeagus 0.12; female proctiger length (FP) $0.92-0.93$.

AL/HW 2.13-2.63; length of apical 2 segments of labium/HW 0.51-0.65; metatibia length/HW 0.94-1.10; WL/HW 5.01-5.61; $\mathrm{WL} /$ fore wing width 3.04-3.17; MP/HW 0.33-0.34; $\mathrm{FP} / \mathrm{HW}$ 
$0.92-0.93$; FP/circum-anal ring length 2.25 - 2.56; female subgenital plate length/FP $075-0.78$.

Fifth instar larva. Coloration. Yellow with reddish brown eyes.

Structure. Body (fig. 8) elongate with narrow, long wing buds. Antennae 7-segmented with each a rhinarium on segments 3 and 5 , and 2 rhinaria on segment 7; segment 3 large, swollen and constricted in the middle. Tarsal arolium triangular, sessile, with short unguitractor. Anus terminal, outer crrcum-anal pore ring strongly convoluted, consisting of a single row of oval pores; inner ring similar to outer ring but much fainter. Dorsal body surface and ventral abdominal surface covered with short setae. Margin of body with simple setae, irregular in length and arrangement, and

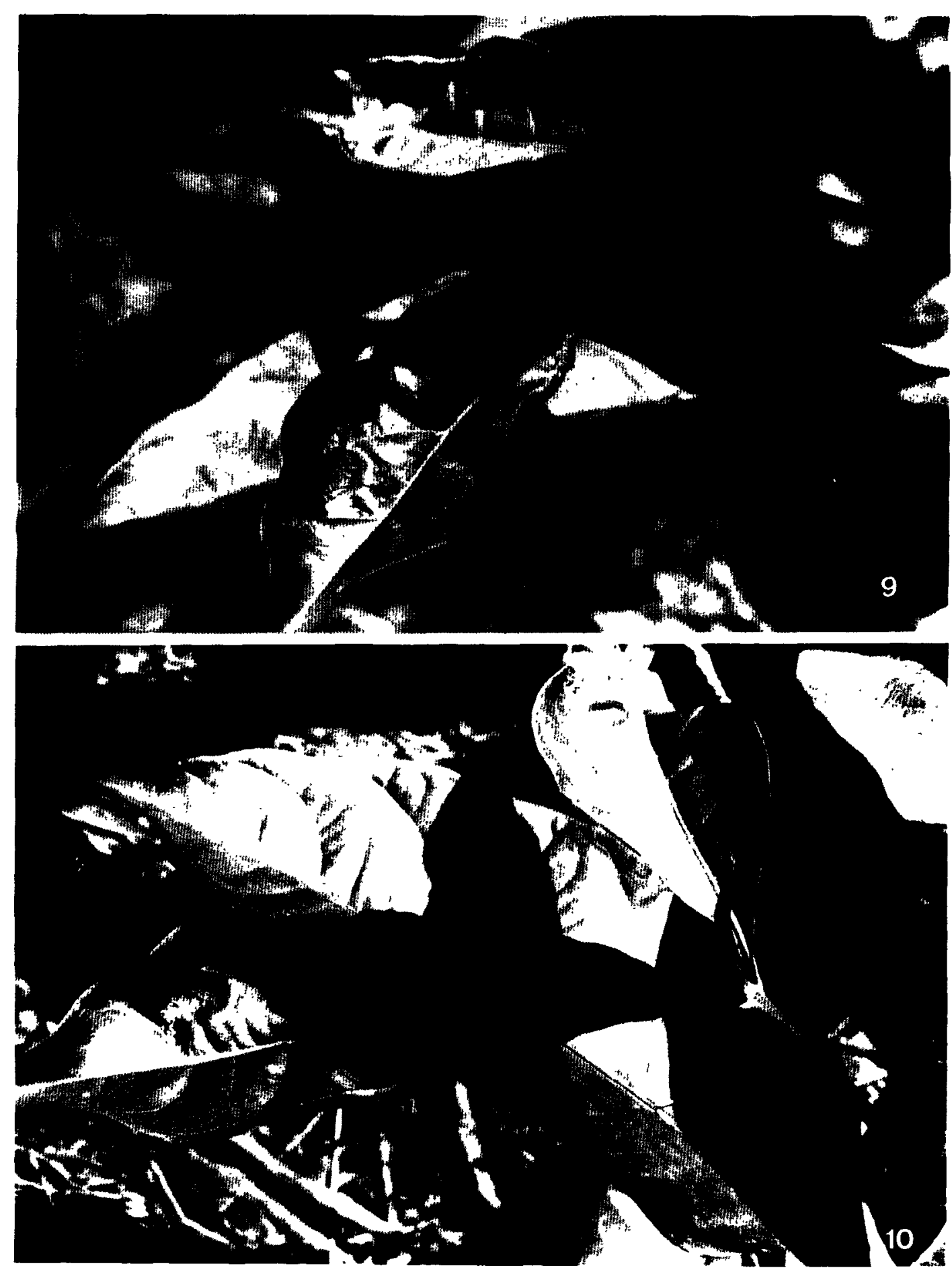

Figs. 9-10 Leuronota calycophyll sp. n. galls on Calycophyllum spruceanum. 
with very slender, apically truncate sectasetae present in following numbers (on one side only): anterior head margin: 3-5; cephalothorax behind eyes. 3-5; fore wing bud: 1 , hind wing bud 1 ; caudal plate 14-19 The sectasetae on the margin of the caudal plate are concentrated mainly terminally and sparse laterally

Measurements in $\mathrm{mm}$ and ratios (3 larvae). Body length (BL) 1.40-1.66; body breadth (BB) $066-085$; fore wing bud length (WL) 0.58-0 65; antenna length 0.31-0.35.

$\mathrm{BL} / \mathrm{BB} 195$ - 2.14; WL/AL 1.86-2,04.

Egg Elongate, about 3 times as long as wide; longitudinal axis parallel to substrate surface, pedicel which is incerted in plant tissue thus laterally Apex pointed. Surface longitudinally rugulose

Material examined Holotype is. PERU. Iquitos $3^{\circ} 45^{\prime} \mathrm{S} 73^{\circ} 15^{\prime} \mathrm{W}$, $125 \mathrm{~m}$ a s.l., Departemento Loreto, San Miguel, 1.vi.1992 (G. Couturier), Calycophyllum spruceanum (Muséum d'Histoire $\mathrm{Na}$ turelle, Genève). Paratypes, PERU $8 \hat{3}, 13 \bar{q}$, same data as holotype; $23 \hat{3}, 7,6$ adults, same but 17.i.1992 ( $\mathrm{G}$ Couturier \& J. Gonzales T) (Muséum d'Histoire Naturelle, Genève; Muséum National d'Historre Naturelle, Parıs; The Natural History Museum, London; Departemento de Entomologia, Unıversıdad Agraria La Molina, Lima; Instituto de Investigaciones de la Amazonia, Peruana, İquitos)

Material excluded from type-series; many larvae of different instars and eggs with the same data and depositories as type-series.

\section{Affinities}

The genus Leuronota Crawford currently includes 21 New World and 8 Oriental species. Brown \& Hodkınson (1988) and Burckhardt (1988) suggested that, based on a series of autapomorphies, the New World species, together with $L$. distincta (Crawford) from the Philippines, form a monophyletic group congeneric with Troza maculata Crawford, the type-species of Leuronota. Leuronota distincta is known from a single female only and its provenance in the Philippines may be erroneous (Brown \& Hodkinson, 1988).

Within Leuronota sensu stricto species are characternzed by the shape of genal processes, fore wing shape, pattern and venation, the distribution of the surface spinules and the morphology of the male terminalia, the female terminalia are relatively homogenous The almost complete absence of genal processes separates $L$. calycophylli from all other known congeners. There are no characters suggesting a closer relationship to any of the described species

The larval morphology is very homogenous within the genus. Accordıng to Burckhardt \& Brown (1992) the last larval instar of Leuronota trichilae Brown \& Hodkinson bears 8-segmented antennae, a single circum-anal $\mathrm{nng}$ and pointed sectasetae. A reexamination of material showed, however, that in $L$. trichliae the antennae are 7 -segmented, the circum-anal pores are arranged in an inner and an outer ring and the sectasetae are apically truncate similar to $L$. calycophyll. The two species seem to differ in the slightly lower number of marginal sectasetae on the caudal plate in L. trichliae. According to Ferris (1928) the sectasetae are pointed in Leuronota maculata (Crawford).

Within Leuronota sensu stricto, L. calycophyll is distinct in its host association with Calycophyllum (Rubiaceae). Other host-plants exploited by Leuronota spp. are Celts (Ulmaceae) (by three Leuronota spp.), Esenbeckia and Fagara (Rutaceae) (each by one sp.), Weinmannia (Cunoniaceae), Cordta (Boraginaceae) and Trichilia (Meliaceae) (each by one sp.). Leuronota leguminicola Crawford was recorded from a fabaceous host which is erroneous (Hollis, pers. comm.). The hosts of the remaining 13 species are unknown.

\section{Biology}

About six months old capirona plants of $50-60 \mathrm{~cm}$ height are heavily attacked by the larvae of $L$. calycophylli. The larval feeding on the young shoots induces marginal rolls on the leaves which are irregularly bulbous and reddish (figs $9-10$ ). The larvae live in the leaf rolls The eggs are laid singly or in small groups along the leaf veins or on the leaf margin.

\section{Acknowledgements}

We thank D. Hollis, London and P. Lauterer, Brno, for comments on the manuscript, and G. Roth, Geneva, for inking the drawings The field work was supported by the aggreement ORSTOM/IIAP.

\section{References}

Brown, R.G. \& Hodkinson, I.D. (1988) Taxonomy and ecology of the jumping plant-lice of Panama (Homoptera. Psyllordea). Entomonograph 9, 1-304.

Burckhardt, D. (1988) Jumping plant lice (Homoptera: Psylloidea) of the temperate neotropical region. Part 3: Calophyidae and Triozidae. Zoological Journal of the Linnean Society 92, 115 191.

Burckhardt, D. (1991) Boreioglycaspis and Spondyliaspidine classification (Homoptera: Psyllordea) Raffles Bulletin of Zoology 39, $15-52$.

Burckhardt, D. \& Brown, R.G. (1992) Larvae of Panamanian jumping plant-lice (Homoptera: Psylloidea). pp. 290-301 in Quintero, D. \& Arello, A. (Eds) Insects of Panama and Mesoamerica, selected studies. Oxford, Oxford University Press

Burckhardt, D. \& Lauterer, P. (1989) Systematics and biology of the Rhinocolinae (Homoptera: Psylloidea). Journal of Natural History 23, $643-712$.

Conci, C. (1992) Spanioza tamaninu sp. n., from Trentino (NE Italy) (Homoptera Psylloidea). Attı della Società Italiana di Scienze Naturali e del Museo Civico di Storia Naturale di Milano 132 (1991), 257-264.

Ferris, G.F. (1928) Observations on the Chermidae (Hemiptera: Homoptera). Part V. Canadian Entomologist 60, 240-245.

Gegechkori, A.M. \& Loginova, M.M. (1990) Psillidy SSSR 164 pp. Tbilisi, Akademiya Nauk Gruzinskoi SSR.

Hodkinson, I.D. (1986) The psyllids (Homoptera: Psylloidea) of the Oriental zoogeographical region an annotated check-list. Journal of Natural History 20, 299-357.

Hodkinson, I.D. \& White, I.M. (1981) The Neotropical Psylloidea (Homoptera: Insecta). an annotated check list. Journal of Natural History 15, 491-523.

Hollis, D. (1984) Afrotropical jumping plant lice of the family Triozidae (Homoptera: Psylloidea). Bulletin of the British Museum (Natural History) (Entomology) 49, I-102.

Hollis, D. (1987a) A new citrus-feeding psyllid from the Comoro Islands, with a review of the Diaphorina amoena species group (Homoptera). Systematic Entomology 12, 47-61.

Hollis, D. (1987b) A review of the Malvales-feeding psylid family Carsideridae (Homoptera). Bulletin of the Britsh Museum (Natural History) (Entomology) 56, 87-127.

Hollis, D. \& Broomfield, P.S. (1989) Ficus-feeding psyllids (Homoptera), with special reference to the Homotomidae. Bulletin of the British Museum (Natural History) (Entomology) 58, $131-183$.

Mabberley, D.J. (1987) The plant-book. A portable dictionary of the higher plants. 707 pp. Cambridge, Cambridge University Press. 
Mani, M.S. (1973) Plant galls of India. 354 pp. Madras, Macmillan India.

Record, S.J. \& Hess, R.W. (1943) Timbers of the world. New Haven, Yale University Press.

Robbrecht, E. (1988) Tropical woody Rubiaceae. Opera Botantca Belgica 1, 1-271.

Uphof, J.C.T. (1968) Dictionary of economic plants. 591 pp. Lehre, J. Cramer Publisher.
White, I.M. \& Hodkinson, I.D. (1985) Nymphal taxonomy and systematics of the Psylloidea. Bulletin of the British Museum (Natural History) (Entomology) 50, 153 -301.

(Accepted 1 February 1994) C CAB INTERNATIONAL, 1994 